\title{
Reforma żydowskiej muzyki liturgicznej w Galicji na przełomie XIX i XX wieku
}

\author{
THE REFORM OF JEWISH LITURGICAL MUSIC IN GALICIA \\ AT THE TURN OF THE NINETEENTH AND TWENTIETH CENTURIES
}

\begin{abstract}
The article presents the issue of the reform of Jewish liturgical music in Galicia at the turn of the nineteenth and twentieth centuries. Its main question concerns the essence of the reform, the novelty of which relied rather on the introduction of a modern way of performance of traditional music than replacing it with a new repertoire. The text discusses the role of new music performers such as cantors, choirs and organists in Galician Temples. It draws attention to the aesthetic changes of synagogue music and its ideological foundations. It also presents the attitude of progressive Galician Jews toward the repertoire of West European synagogues as well as to the music composed by local orthodox cantors, such as Baruch Schorr, Baruch Kinstler or Eliezer Goldberg. As the analysis of the historical material shows, their musical tastes and strong attachment to tradition tied them more closely to the Galician orthodoxy than to the German reform.
\end{abstract}

Keywords: Galician Jews, synagogue music reform, Eliezer Goldberg, Baruch Kinstler, Baruch Schorr.

Słowa kluczowe: Żydzi galicyjscy, reforma muzyki synagogalnej, Eliezer Goldberg, Baruch Kinstler, Baruch Schorr.

Przedwojenna żydowska muzyka liturgiczna Europy Środkowo-Wschodniej zdaje się podzielać los jej twórców. Podobnie jak Ostjuden poddana została stereotypizacji, a niekiedy deprecjacji. Ceniona za swoją ekspresyjność, jest lekceważona ze względu na niski poziom produkcji i wykonawstwa artystycznego. W literaturze przedmiotu opisuje się ją jako nieuległą 
procesom modernizacji i europeizacji, gdyż: „większość Żydów tutaj nie była wyzwolona, nie uczestniczyła w życiu operowym i koncertowym, nie było tu pozytywnej emocjonalnie odpowiedzi na muzykę wielkich kompozytorów zachodniej Europy"1.

W świetle aktualnych badań nad życiem muzycznym społeczności żydowskiej w międzywojennej Polsce stwierdzenie to jest jednak krzywdzące. Choć stopień przywiązania społeczności żydowskiej do kultury tradycyjnej był tu bardzo wysoki, nie powstrzymał zupełnie procesu przemian. Przekornie wypada postawić pytanie: czy miłość do własnej tradycji muzycznej tym bardziej nie motywowała do zachowania jej dla przyszłych pokoleń przez uatrakcyjnienie i przełożenie na język bardziej zrozumiały dla młodszych odbiorców?

Wspomniany proces modernizacji muzyki synagogalnej Europy Środkowo-Wschodniej bywa niekiedy niedostrzegany również na skutek zbyt uproszczonego rozumienia tego zjawiska, które utożsamia się z adaptacją twórczości reformatorów zachodnioeuropejskich. W tym znaczeniu ogranicza się zainteresowanie reformą do elitarnych kręgów wschodnioeuropejskiej społeczności żydowskiej, traktując ich przedstawicieli jako światłe wyjątki na tle ogółu:

było kilku kantorów w Rosji, którzy dążyli do polepszenia statusu kantora na Wschodzie i z zazdrością obserwowali reformę muzyki u Sulzera, Naumbourga i Lewandowskiego. Znali oni powstałą pod wpływem Zachodu muzykę klasyczną rosyjskiej i polskiej arystokracji i starali się przystosować do kultury panującej wśród klas wyższych².

Spojrzenie to podkreśla aspekt społeczny zjawiska modernizacji żydowskiej muzyki liturgicznej, odwraca jednak uwagę od szeroko rozumianych przemian muzycznych. Traktuje reformę jako proces charakterystyczny wyłącznie dla zachodu Europy i rozszerzający się wyłącznie poprzez zaakceptowanie i naśladowanie jej zdobyczy, tracąc z pola widzenia te zjawiska, które go rzeczywiście konstytuowały, a mianowicie: profesjonalne kształcenie i wyodrębnienie zawodu kantora synagogalnego, wprowadzanie do synagog chórów i organów oraz przygotowanie nowych opracowań tradycyjnych melodii liturgicznych dla nowych wykonawców. Jego inspiracją i konsekwencją była przemiana myśli o muzyce. Zmieniła się rola

${ }^{1}$ Emanuel Rubin, John H. Baron, Music in Jewish History and Culture, Sterling Heights 2006, s. 168. Przekłady cytatów z języka angielskiego i jidysz w tym artykule zostały dokonane przez autorkę.

2 Tamże. 
opracowania muzycznego liturgii, które stało się odtąd nie tylko „sługą słowa”, realizacją i kontynuacją muzycznych tradycji, ale w myśl estetyki epoki muzyka w nabożeństwie zyskała rangę sztuki, autonomicznego komponentu akcji liturgicznej ${ }^{3}$. Patrząc przez pryzmat tych przemian na muzykę synagog galicyjskich przełomu XIX i XX w., nie sposób nie dostrzec podobieństw do zjawisk zachodzących na zachodzie Europy. Co więcej, dotyczą one nie tylko muzyki uprawianej przez społeczności określające siebie mianem postępowych, ale też śpiewu liturgicznego galicyjskiej ortodoksji.

Niniejszy artykuł jest próbą nakreślenia ram dla pełniejszego omówienia zagadnienia modernizacji muzyki synagogalnej Galicji przełomu XIX i XX w. Korzystając z zachowanych materiałów prasowych, wspomnień i opracowań historycznych, wskażę na przeobrażenia „techniczne” dokonujące się w galicyjskich synagogach: profesjonalizację i specjalizację zawodową muzyków synagogalnych, obecność tam chórów i instrumentów. Następnie omówię zagadnienie recepcji zachodnioeuropejskiej reformowanej muzyki liturgicznej w Galicji, jej adaptację i krytykę. Przedstawię też założenia „reformy” lokalnego repertuaru synagogalnego. W ostatniej części scharakteryzuje jej ostateczny produkt, tj. zachowane kompozycje kantorów: Barucha Schorra (1823-1904) z lwowskiej synagogi Miejskiej, Barucha Kinstlera (1846-1934) z lwowskiej synagogi Przedmiejskiej i Eliezera Goldberga (1843-1920) z krakowskiej synagogi Kupa, które podsumowują, a także w zaskakujący i piękny sposób wieńczą marzenia o nowym repertuarze synagogalnym - łączącym lokalne tradycje z europejską muzyką artystyczną.

\section{Zwiastuny reformy: kantorzy, chóry i organy w galicyjskich synagogach}

Reforma żydowskiej muzyki liturgicznej jako pochodna haskali wprowadzała nowe europejskie reguły estetyki do synagogi. Zakładała: „uporządkowanie, spokój, większą elegancję, zwracanie uwagi na stosowność,

${ }^{3}$ Alicja Maślak-Maciejewska, Modlili się w Templu. Krakowscy Żydzi postępowi w XIX wieku. Studium społeczno-religijne, Kraków 2018, s. 245-258; Halina Goldberg, "On the Wings of Aesthetic Beauty Toward the Radiant Spheres of the Infinite": Music and Jewish Reformers in Nineteenth-Century Warsaw, „The Musical Quarterly” 101 (2018), nr 4. Zob. też: Enrico Fubini, Historia estetyki muzycznej, tłum. Zbigniew Skowron, Kraków 2002, s. 254-331. 
decorum"4. Miała służyć zharmonizowaniu nowych postaw społecznych inteligencji żydowskiej z tradycyjną religijnością żydowską. W praktyce wiązała się z wprowadzeniem nowego wystroju synagogi, nowych szat liturgicznych, uporządkowaniem akcji liturgicznej, a także z europeizacją muzyki synagogalnej tworzonej i wykonywanej przez i dla wykształconych w kulturze europejskiej żydowskich muzyków i słuchaczy. Zakładała

[organizację] nabożeństw na nowy sposób, z udziałem chóru, organów i kazań. Inteligencji żydowskiej, którą odtąd dopuszczano do szkót, uniwersytetów i innych wolnych zawodów, było to bardzo na rękę, bo przy wykonywaniu swojego zawodu (adwokata, lekarza, sędziego, wojskowego itd.) mieli nadal możność pozostania i wyżycia się w swej społeczności religijnej bez reszty 5 .

Co ważne, wprowadzonych zmian reformatorzy nie postrzegali jako ingerencji w istotę własnej religijności, a jedynie jako modernizację zewnętrznych form jej wyrazu.

Gwarantem piękna oprawy muzycznej liturgii miał być utalentowany kantor. Wybitny śpiewak na tym stanowisku przyciągał rzesze modlących się i w ten sposób budował renomę miejsca, w którym był zatrudniony. Tak wspomina Majer Bałaban pierwszego kantora lwowskiego Templu, Ozjasza Abrasa:

Wszyscy członkowie zarządu starali się o podtrzymanie prestiżu templu i powagi nabożeństw w nim odprawianych, co im się częściowo udawało dzięki wielkiej popularności Abrasa. Ilekroć Abras stawał przed ołtarzem, zapełniała się świątynia po ostatnie miejsce, a zaglądali do niej czasem i młodsi ortodoksi, już to dla ciekawości [...], już to dla posłuchania pięknego śpiewu kantora i zharmonizowanego chóru'.

Od kantora, inaczej niż w przypadku dotychczasowego tradycyjnego chazana, wymagano przede wszystkim odpowiednich predyspozycji muzycznych ${ }^{7}$. Nowoczesny kantor powinien być zawodowym muzykiem, utalentowanym śpiewakiem. Jego walory moralne i religijne miały znaczenie drugorzędne wobec uzdolnień i przygotowania muzycznego. Tymczasem jeszcze w 1926 r. w krakowskiej ortodoksyjnej synagodze Starej poszukiwano chazana przede wszystkim „o nieskazitelnym charakterze,

${ }^{4}$ Maślak-Maciejewska, Modlili się w Templu..., s. 245.

${ }_{5}^{5}$ Mojżesz Weissman, Szlakami religijnej myśli postępowej Żydów galicyjskich, „Tygodnik Żydowski” (1938), nr 42, s. 2.

${ }^{6}$ Majer Bałaban, Historia lwowskiej synagogi postẹpowej, Lwów 1937, s. 68. Bałaban, podobnie jak w innych swoich tekstach, ołtarzem nazywa aron ha-kodesz.

${ }^{7}$ Por. Tina Frühauf, Salomon Sulzer: Reformer, Cantor, Icon, Berlin 2012, passim. 
religijnego”, a następnie - „muzykalnego, samodzielnego z głosem tenorowym lub barytonowym, nieprzekraczającego 40 lat". . Relacje Majera Bałabana dowodzą, że w II połowie XIX w. we lwowskim Templu kantora postrzegano przede wszystkim jako artystę, którego ambicje kolidowały niekiedy z właściwą postawie religijnej skromnością i poczuciem służby wobec współwyznawców9 .

Od kantorów społeczności postępowych oczekiwano również umiejętności czytania nut i posługiwania się partyturą, koniecznych do wykonywania dzieł chóralnych. Zatrudnionego w 1880 r. we lwowskim Templu Edwarda Darewskiego wkrótce zwolniono, gdyż nie potrafił współpracować z chórem i jego dyrygentem. Jak relacjonował Bałaban:

Ton podawał stale dyrygent i chór tenże ton podejmował. Cóż jednak mógł zrobić dyrygent, kiedy Darewski od razu wypadał z tonu i pociągał za sobą część chórzystów. Na tle kakofonii przychodziło do sporów, które spowodowały nawet rozłam wśród członków zarządu Templu; większość żądała natychmiastowego usunięcia „niemuzykalnego”, a przy tym aż nadto dumnego kantora ${ }^{10}$.

Umiejętność czytania partytur była potrzebna do wykonania dzieł kompozytorów i kantorów zachodnioeuropejskich - Salomona Sulzera, Louisa Lewandowskiego czy Samuela Naumbourga - przeznaczonych dla kantora i chóru. Stały się one symbolami postępu i jako takie zostały włączone do repertuaru liturgicznego galicyjskich Templów. Postrzegano je jako nośnik informacji o tożsamości i aspiracjach społecznych żydowskiej inteligencji gromadzącej się we wschodnioeuropejskich ,synagogach chóralnych", którym to terminem określano postępowe synagogi w Rosji i na Kresach Wschodnich. Spojrzenie to doskonale ilustruje relacja Pinchasa Minkowskiego, który wspominając własne starania o zatrudnienie we lwowskiej synagodze postępowej, cytował ostrzeżenie wystosowane pod jego adresem przez jednego z członków zarządu, dra Landesbergera:

${ }^{8}$ Konkurs na posadę chazena, „Nowy Dziennik” (1926), nr 260, s. 1.

9 Zob. Bałaban, Historia lwowskiej synagogi... Przykładami mogą tu być: próżność Ozjasza Abrasa dążącego do zaimponowania kręgom inteligencji żydowskiej opowiadaniem o swojej rzekomej nauce u Franciszka Liszta (s. 41), postawa Edwarda Darewskiego nadużywającego autorytetu nadkantora w celu zdyskredytowania „konkurencji” (s. 102-103), złamanie zasad dyscypliny i przekroczenie norm obyczajowych przez Izaaka Halperna publikującego satyrę na swoich synagogalnych przełożonych (s. 186) czy powszechne już zjawisko porzucania przez kantorów dotychczasowej posady dla osiągnięcia większych korzyści materialnych i prestiżu w innych ośrodkach.

${ }_{10}$ Tamże, s. 102. 
Wiemy, że silną i zasadniczą stroną Pańskiego śpiewu jest pieśń tradycyjna, lecz naszego templu nie wolno „zażydzać” i dlatego zechce Pan śpiewać wyłącznie pieśni „chóralne” i zupełnie zaniechać tzw. pieśni żydowskich. W dwóch innych synagogach naszego miasta modlą się kantorzy: Baruch Schorr i Aron Szalom (Schierman) i oni modlą się zupełnie tradycyjnie, my natomiast mamy upodobanie w śpiewie „nowym”11.

Słowa te wskazują przede wszystkim na chęć odróżnienia się inteligencji żydowskiej od niewykształconej i niezeuropeizowanej większości rodzimej społeczności.

Wydaje się, że adaptacja zachodnioeuropejskiego repertuaru była poniekąd koniecznością powodowaną brakiem własnych opracowań chóralnych rodzimych melodii. Nie wynikała ani z chęci wprowadzenia radykalnej zmiany w lokalnych tradycjach, ani z powszechnego zachwytu twórczością Sulzera, Lewandowskiego i innych kompozytorów zachodnioeuropejskich. Jak stwierdzali sami reformatorzy, jedynym, co różniło ich od ortodoksji, był sposób modlitwy, nie zaś wykładnia religijna ${ }^{12}$. Stąd też istotą reformy muzycznej nie było odrzucenie muzyki tradycyjnej, lecz nowy sposób jej wykonawstwa. Z punktu widzenia środowisk postępowych kantorzy synagogalni mogli być zatrudniani naprzemiennie przez społeczności ortodoksyjne i postępowe. W tym drugim gronie zyskali też z czasem możliwość wykonywania tradycyjnych melodii wschodnioeuropejskich. Taką interpretację usprawiedliwia jeszcze jedna relacja Minkowskiego, który - przymuszony do śpiewania „Sulzerowskich arii barytonowych” we lwowskim Templu - zakończył swój występ tradycyjną wersją modlitwy „Aw ha-rachamim”. Reakcją lwowskich postępowych „neofitów” były wówczas wypowiedziane przez Natana Meyera słowa: „prosimy pana imieniem całego zgromadzenia synagogalnego, byś musaf modlił się po żydowsku, gdyż jak się przekonaliśmy z »Ow Harachamim «i tradycyjne melodie brzmią w twych ustach inaczej, aniżeli u kantorów, których dotychczas słyszeliśmy!"13.

Novum synagog postępowych było wprowadzenie czterogłosowego chóru. Obecność takiego zespołu z konieczności wiązała się z europeizacją wykonywanego w nich repertuaru. Nawet jeśli podstawą tego ostatniego były melodie tradycyjne, musiały one zostać rozpisane na czterogłosowy zespół wokalny i zharmonizowane zgodnie z regułami europejskiej muzyki

\footnotetext{
1 Tamże, s. 105.

2 Zob. Maślak-Maciejewska, Modlili się w Templu..., s. 268-269.

${ }^{13}$ Cyt. za: Bałaban, Historia lwowskiej synagogi..., s. 109.
} 
artystycznej, która stworzyła bogatą tradycję posługiwania się tym zespołem i wypracowała różnorodne techniki czterogłosowej kompozycji chóralnej. I choć, jak podaje Neil Levin, śpiew chóralny był nieodłączną częścią historii muzyki synagogalnej w całej Europie, to wprowadzenie instytucji „synagogi chóralnej” należy interpretować jako chęć podkreślenia nowego, zachodnioeuropejskiego sposobu tworzenia go, który wyróżniał nowo powstałe instytucje na tle praktyki dotychczasowych ${ }^{14}$.

Pierwsze chóry synagogalne pojawiły się w Niemczech. Najstarszy stworzył w 1810 r. Israel Jacobsohn i był to chłopięco-męski chór synagogi w Seesen w Dolnej Saksonii ${ }^{15}$. Chórzystami zostali uczniowie lokalnej szkoły żydowskiej oraz modlący się w tej społeczności mężczyźni. W Galicji pierwszy chór założono prawdopodobnie we Lwowie, gdzie do skompletowania go zobowiązał się pierwszy kantor lwowskiego Templu, Ozjasz Abras, podpisując 28 kwietnia 1844 r. umowę z zarządem Stowarzyszenia Postępowego ${ }^{16}$. Również w Krakowie chór templowy udało się skompletować w 1844 r. ${ }^{17}$ Daty wprowadzenia chórów w stowarzyszeniach postępowych ważnych ośrodków europejskich oraz miast dawnej Galicji zaprezentowano na osi czasu ${ }^{18}$.

Daty wprowadzenia chórów do synagog postępowych w wybranych ośrodkach europejskich i galicyjskich

\begin{tabular}{|c|c|c|c|c|c|c|c|c|c|}
\hline $\begin{array}{c}\text { Seesen } \\
1810\end{array}$ & $\begin{array}{c}\text { Frankfurt } \\
1816\end{array}$ & $\begin{array}{c}\text { Hamburg } \\
1818\end{array}$ & $\begin{array}{l}\text { Lipsk } \\
1820\end{array}$ & $\begin{array}{c}\text { Praga, } \\
\text { Kopen- } \\
\text { haga } \\
1838\end{array}$ & $\begin{array}{l}\text { Tarnopol } \\
\text { po } 1839\end{array}$ & $\begin{array}{c}\text { Wrocław, } \\
\text { Berlin, } \\
\text { Drezno } \\
1840\end{array}$ & $\begin{array}{c}\text { Londyn } \\
1841\end{array}$ & $\begin{array}{l}\text { Lwów, } \\
\text { Kraków } \\
1844\end{array}$ & $\begin{array}{c}\text { Stanisła- } \\
\text { wów } \\
1870\end{array}$ \\
\hline
\end{tabular}

Pierwsze chóry stowarzyszeń postępowych Galicji, podobnie jak same organizacje, powstały niewiele później niż ich europejskie pierwowzory.

${ }^{14}$ Neil W. Levin, Zavel Zilberts, Milken Archive of Jewish Music, https://www.milkenarchive.org/artists/view/zavel-zilberts/ [dostęp: 28 stycznia 2019].

15 Tina Frühauf, The Organ and Its Music in German-Jewish Culture, New York 2012, s. 27-44; Aron Marko Rothmüller, The Music of the Jews: An Historical Appreciation, Cranbury 1975 , s. 124-139.

${ }_{16}$ Bałaban, Historia lwowskiej synagogi ..., s. 42.

${ }^{17}$ Freistaat Krakau, „Der Orient” (1844), nr 24, s. 189-190, za: Maślak-Maciejewska, Modlili się w Templu..., s. 251.

${ }_{18}$ Na podstawie: Bałaban, Historia lwowskiej synagogi..., s. 41-42; Leon Streit, Dzieje synagogi postępowej w Stanisławowie, Stanisławów 1939, s. 2-4; Rothmüller, The Music of the Jews..., s. 124-139; Maślak-Maciejewska, Modlili się w Templu..., s. 251-255; Rachel Manekin, The Prayer House of a Galician Maskil: Joseph Perl's Synagogue Regulations, „Association for Jewish Studies Review” 42 (2018), nr 2, s. 403-440. 
Stosunkowo wcześnie wprowadzono też w Galicji chóry mieszane. Lwów zdecydował się na ten krok już w 1893 r. ${ }^{19}$ Być może inspiracją byli tu wiedeńczycy, którzy dopuścili chór mieszany do udziału w liturgii przynajmniej rok wcześniej ${ }^{20}$. W synagogach praskich chóry mieszane działały już w latach osiemdziesiątych XIX w., na przykład w synagodze Maisela odnotowano istnienie takiego chóru w roku $1883^{21}$. W latach dziewięćdziesiątych kobiety śpiewały w synagogach czeskich w Karlsbadzie, Tachau, Troppau i Jägerndorf ${ }^{22}$. Nie osłabiło to oczywiście kontrowersji wokół decyzji zarządu lwowskiego Templu. Wręcz przeciwnie, spodziewać się można, że dodatkowo wzmocniło je zaproszenie do śpiewu chórzystek zatrudnionych w teatrach polskich i żydowskim we Lwowie. Jeszcze w 1891 r. suspendowano tutaj kantora ortodoksyjnej synagogi Miejskiej, Barucha Schorra, za sam fakt pojawienia się we Lwowskim Teatrze Żydowskim, w którym odbywała się premiera jego operetki Szimszon ha-gibor. Schorr został zawieszony na cztery tygodnie w obowiązkach kantora, a urażony karą - na pięć lat opuścił Lwów ${ }^{23}$. W czasie jego nieobecności jednak „zachowawczo-postępowa” społeczność Lwowa zaprosiła kobiety-aktorki do śpiewu w chórze synagogalnym ${ }^{24}$.

Podobne „odważne” decyzje podjęły także inne galicyjskie społeczności. W okresie międzywojennym chóry mieszane działały przy synagogach postępowych Krakowa i Stanisławowa ${ }^{25}$. Nie wiadomo, jaki chór zorganizował Becalel Kinstler w Tarnowie, obejmując tam posadę dyrygenta

${ }^{19}$ Bałaban, Historia lwowskiej synagogi..., s. 146.

${ }^{20}$ Kleine Chronik, „Oesterreichisch-ungarische Cantoren-Zeitung” (1892), nr 30, s. 5. Za wskazanie tego źródła dziękuję Marcie Stellmacher z Hochschule für Musik, Theater und Medien w Hanowerze.

${ }^{21}$ Anständige, stimmbegabte Mädchen..., „Prager Tagblatt” (1883), nr 347, s. 22. Za wskazanie tego źródła również dziękuję Marcie Stellmacher.

${ }^{22}$ Kleine Chronik. Tachau, 31. Jänner, „Oesterreichisch-ungarische Cantoren-Zeitung” (1891), nr 5, s. 6-7; Kleine Chronik. Karlsbad, „Oesterreichisch-ungarische Cantoren-Zeitung” (1891), nr 16, s. 7; Kleine Chronik. Troppau, 15. Februar, „Oesterreichisch-ungarische Cantoren-Zeitung” (1895), nr 6, s. 7; Verschiedene Nachrichten. Jägerndorf, „Die Wahrheit” (1899), nr 8, s. 14-15. Za wskazanie wymienionych tu źródeł dziękuję Marcie Stellmacher.

${ }^{23}$ Zob. Zalman Zylbercwajg, Schorr Baruch, [w:] Leksikon fun jidiszn teater, t. 3, red. Zalman Zylbercwajg, New York 1959, s. 2141; Marsha Bryan Edelman, Discovering Jewish Music, Philadelphia 2003, s. 65.

${ }^{24}$ Bałaban, Historia lwowskiej synagogi..., s. 147.

${ }_{25}$ Streit, Dzieje synagogi postepowej..., s. 45, 95; Arje Brauner, Kach hitpalelu Jehudej Krakow, [w:] Ha-Jechudim be-Krakow - Chajeha we-churbana szel kehila atika, red. Shimon Lazar, Hajfa 1981, s. 200; Sylwia Jakubczyk-Ślęczka, Życie muzyczne społeczności żydowskiej na terenach dawnej Galicji w okresie międzywojennym, Kraków 2018, maszynopis pracy doktorskiej, Uniwersytet Jagielloński, Wydział Historyczny, s. 127. 
ok. 1934 r., po zakończeniu współpracy z lwowską społecznością postępową ${ }^{26}$. Ostatecznie nie jest też pewne, jakie konkretnie funkcje spełniały chóry mieszane - czy towarzyszyły liturgii, czy też wyłącznie koncertom świątecznym, ślubom i nabożeństwom patriotycznym? Odpowiedź na te pytania wymaga jeszcze dalszych badań.

Wraz z chórami w synagogach postępowych pojawiały się też instrumenty. Pierwsze organy wprowadził do synagogi w Seesen wspomniany już Israel Jacobsohn w 1810 r. ${ }^{27}$ Jednak dyskusje na temat ich obecności i zasadności użycia w synagogach w różnych okolicznościach trwały przez cały wiek XIX. W ośrodku wzorcowym dla reformy galicyjskiej, tj. Wiedniu, fisharmonia pojawiła się pod koniec XIX w. ${ }^{28} \mathrm{~W}$ Pradze tradycja użycia organów i innych instrumentów w synagogach sięgała nawet XVI w., jednak sposób ich stosowania analogiczny do tego, jaki wypracowywały społeczności postępowe w XIX w., przyjęto tutaj ok. roku $1837^{29}$. W Krakowie fisharmonia zabrzmiała podczas otwarcia synagogi Tempel w $1861 \mathrm{r}$. ${ }^{30}$, we Lwowie zaś zakupiono ją w roku 1887, a w 1897 wymieniono na organy ${ }^{31}$. W Przemyślu instrument ten towarzyszył otwarciu Templu 14 września 1890 r. ${ }^{32}$ W 1927 r. fisharmonia pojawiła się w Stanisławowie ${ }^{33}$. Własny instrument (nie wiadomo jaki) w okresie międzywojennym posiadał również Tarnów ${ }^{34}$.

Wydaje się, że użycie organów w galicyjskich synagogach postępowych było w różny sposób ograniczane. W synagodze lwowskiej na stanowisku organisty zatrudniano wyłącznie nie-Żydów ${ }^{35}$. Pierwszym organistą był profesor lwowskiego konserwatorium, Wojnowski, który akompaniował liturgii również w czasie szabatu. Okazjonalnie grywał w synagodze lwowskiej dyrektor konserwatorium prof. Schwarz. Nie wykonywał tam jednak kompozycji liturgicznych, lecz „występował” z repertuarem klasycznym podczas

${ }^{26}$ Zob. Bałaban, Historia lwowskiej synagogi..., s. 241. Najwcześniejsza wzmianka prasowa potwierdzająca obecność Becalela Kinstlera w Tarnowie pojawia się w notatce $Z$ okazji 50-lecia istnienia Ruchu Syjonistycznego..., „Tygodnik Żydowski” (1934), nr 20, s. 1.

${ }^{27}$ Frühauf, The Organ and Its Music..., s. 28.

28 Tamże, s. 39.

29 Tamże, s. 22-24.

${ }^{30}$ Maślak-Maciejewska, Modlili się w Templu..., s. 255-258.

${ }^{31}$ Bałaban, Historia lwowskiej synagogi ..., s. 145-148.

32 Otwarcie nowej synagogi, „Gazeta Przemyska” (1890), nr 75, s. 3.

33 Streit, Dzieje synagogi postępowej..., s. 107.

${ }^{34}$ Kronika tarnowska. Uroczystości poświęcenia sztandaru..., „Nowy Dziennik” (1935), nr 305, s. 15.

${ }^{35}$ Bałaban, Historia lwowskiej synagogi..., s. 146. 
szczególnie uroczystych wydarzeń ${ }^{36}$. W 1922 r. Wojnowskiego zastąpił inny organista lwowskiego konserwatorium, Karol Fuks, polecony przez prof. Rangla, który sam także okazjonalnie grywał we lwowskim Templu ${ }^{37}$. Zatrudnianie nie-Żydów w roli organistów pozwalało zapobiec łamaniu melachot i w przypadku awarii instrumentu w szabat nikt ze społeczności żydowskiej nie naruszał prawa religijnego. Mimo to opór wobec użycia instrumentu w soboty był silny. Po ustąpieniu rabina Cary nowy rabin lwowskiej społeczności postępowej, Lewin, wyraźnie ograniczył użycie organów w liturgii38

Nie jest znany dokładny zakres użycia fisharmonii przez inne społeczności postępowe Galicji. Przypuszczać wolno, że był on węższy. W Krakowie fisharmonia miała towarzyszyć przede wszystkim uroczystościom patriotycznym oraz koncertom świątecznym ${ }^{39}$. Prawdopodobnie tak samo było w innych ośrodkach galicyjskich, tym bardziej że organistami w tych społecznościach byli jej członkowie. Na fisharmonii krakowskiego Templu grał Leibling, w Stanisławowie - Zygmunt Goldfarb, członek tamtejszego Żydowskiego Towarzystwa Muzyczno-Dramatycznego i nauczyciel muzyki w lokalnym Gimnazjum Żydowskim ${ }^{40}$. Wobec zachowawczego charakteru galicyjskiej reformy można przypuszczać, że żaden z nich nie akompaniował liturgii szabatowej.

Wśród przemian muzycznych zachodzących w synagogach postępowych na przełomie XIX i XX w. wyraźnie zarysowuje się rosnąca specjalizacja zawodowa muzyków synagogalnych. Chazan, który pełnił dotąd różne funkcje (często również szocheta czy innego urzędnika gminnego), teraz stał się zawodowym śpiewakiem, kantorem. Jako muzyk mógł być

${ }^{36}$ Tamże, s. 147. Tu i dalej - niektóre z wymienianych w źródłach osób znane są jedynie $\mathrm{z}$ nazwiska.

37 Alfred Plohn, Koncert synagogalny Żydowskiego Towarzystwa Muzycznego, „Chwila” (1921), nr 1056, s. 5; Koncert chanukowy, „Chwila” (1922), nr 1368, s. 5; Bałaban, Historia lwowskiej synagogi..., s. 146, 241.

${ }^{38}$ Do 1928 r. organy akompaniowały piątkowym nabożeństwom i wszystkim świętom poza Rosz ha-Szana i Jom Kippur. Po roku 1928 towarzyszenie organów ograniczono do świąt Pesach, Szawuot i Sukot, a w szabat jedynie do liturgii piątkowej i modlitwy Borchu. Zob. tamże, s. 148.

39 Zob. Kronika. Nadkantor p. Dywiński..., „Nowy Dziennik” (1918), nr 141, s. 4; Kronika. Z okazji Chanuki..., „Nowy Dziennik” (1919), nr 261, s. 3; Alicja Maślak-Maciejewska, Wydarzenia patriotyczne organizowane w synagodze Tempel w Krakowie, [w:] Synagoga Tempel $i$ środowisko krakowskich Żydów postępowych, red. Michał Galas, Kraków-Budapeszt 2012, s. 127-128.

${ }^{40}$ Zob. Streit, Dzieje synagogi postępowej..., s. 107; Alicja Maślak-Maciejewska, Poza działalnościa Ozjasza Thona - synagoga Tempel i krakowskie Stowarzyszenie Izraelitów Postępowych w okresie międzywojennym, „Kwartalnik Historii Żydów” (2016), nr 1, s. 135, 140 (na podstawie Archiwum Żydowskiego Instytutu Historycznego [dalej: AZZIH], Stowarzyszenia krakowskie, sygn. 80, 81). 
nauczycielem w szkole żydowskiej, dyrygentem chóru synagogalnego, ale i te role coraz częściej rozdzielano ${ }^{41}$. Osobnym stał się zawód dyrygenta i organisty w synagogach postępowych. Na obu stanowiskach zatrudniano zawodowych muzyków. We lwowskim Templu dyrygentem chóru synagogalnego przez ponad czterdzieści lat był Abraham Kapłan, współpracujący również z chórami teatralnymi ${ }^{42}$. Po jego śmierci posadę tę objął Izrael Fajwiszys, jeden z najwybitniejszych żydowskich dyrygentów chóralnych i aranżerów pieśni żydowskiej w międzywojennej Polsce. Kolejnym dyrygentem chóru templowego został Becalel Kinstler, syn zasłużonego lwowskiego kantora Barucha Kinstlera. W 1932 r. zastapił go Adolf Gimpel, ojciec wybitnych muzyków - Jakuba, Bronisława i Karola - syn dyrektora Teatru Żydowskiego Jakuba Bera, a po jego śmierci kierownik muzyczny Teatru $^{43}$. W Krakowie chórem templowym dyrygował również Fajwiszys, następnie zaś Izaak Lust, lekarz, krytyk muzyczny, współzałożyciel Stowarzyszenia Przyjaciół Muzyki Żydowskiej4.

Profesjonalizacja i specjalizacja muzyków synagogalnych szła w parze ze wzrostem poważania dla wykonywanych przez nich zadań i przekładała się na ich płace. Te ostatnie pochłaniały - jak na przykład w obrębie lwowskiej społeczności postępowej w 1862 r. - nawet ponad połowę rocznych wydatków na utrzymanie całego personelu synagogalnego ${ }^{45}$. Także w Krakowie w latach 1931-1932 na pensje dla członków chóru synagogalnego przeznaczono niemal 20 procent całego budżetu Stowarzyszenia Izraelitów Postępowych ${ }^{46}$. Trudno o bardziej przekonujący dowód „docenienia” walorów estetycznych liturgii wśród galicyjskich środowisk postępowych.

${ }^{41}$ Zob. Benjamin Matis, An Annotated Translation of Pinchas Szerman's "Poilishe Khazones in Fargangenheitun Tzukunft" [The Polish Cantorate in the Past and the Future], 1924, „Scripta Judaica Cracoviensia” 14 (2016), s. 99-109; Jakubczyk-Ślęczka, Życie muzyczne..., s. 218-223.

${ }^{42}$ Bałaban, Historia lwowskiej synagogi..., s. 145-146.

${ }^{43}$ Tamże, s. 241. Zob. też: Leon Tadeusz Błaszczyk, Fajwiszys Izrael, [w:] tenże, Żydzi w kulturze muzycznej ziem polskich w XIX i XX wieku. Stownik biograficzny, Warszawa 2014, s. 65; tenże, Gimpel Adolf, [w:] tenże, Żydzi w kulturze muzycznej..., s. 80; tenże, Kaplan Abraham, [w:] tenże, Żydzi w kulturze muzycznej..., s. 127; tenże, Künstler Becalel, [w:] tenże, Żydzi w kulturze muzycznej..., s. 146.

44 Isachar Fater, Muzyka żydowska w Polsce w okresie międzywojennym, Warszawa 1997, s. 66; Sylwia Jakubczyk-Ślęczka, La musique juive à Cracovie de l'entre-deux-guerres selon les informations du journal «Nowy Dziennik», „Scripta Judaica Cracoviensia” 9 (2011), s. 121-135; taż, Życie muzyczne..., s. 47-48, 179 [Aneks]; Maślak-Maciejewska, Modlili się w Templu..., s. 251-255.

45 Bałaban, Historia lwowskiej synagogi..., s. 85.

${ }^{46}$ Maślak-Maciejewska, Poza działalnościa Ozjasza Thona..., s. 140 (na podstawie AŻIH, Stowarzyszenia krakowskie, sygn. 80). 


\section{Recepcja reformy zachodnioeuropejskiej: adaptacja i krytyka}

Pierwsze dekady XIX stulecia w Galicji to czas entuzjastycznej adaptacji wiedeńskiego modelu reformy muzyki liturgicznej. Galicyjskie społeczności postępowe chętnie zatrudniały kantorów kształconych przez Salomona Sulzera. Pierwszym kantorem pierwszej społeczności postępowej Galicji - w Tarnopolu - był uczeń Sulzera, Ozjasz Abras, który następnie przeniósł się do Lwowa ${ }^{47}$. Sam zarząd lwowskiego Templu, poszukując kantora, zwrócił się do Sulzera z prośbą o polecenie stosownego śpiewaka ${ }^{48}$. Swoista „Sulzermania” środowiska lwowskiego sprawiła, że zachwycano się kantorami barytonami, do których grona należał Ozjasz Abras, zastępujący go niekiedy Menkes, a także kolejny uczeń Sulzera na stanowisku nadkantora lwowskiej synagogi postępowej, Izaak Halpern ${ }^{49}$. Jak wspomina Pinchas Minkowski, również jemu, gdy ubiegał się o posadę nadkantora we lwowskim Templu, nakazano śpiewać Sulzerowskie ,arie barytonowe” - mimo iż wykraczały poza skalę jego głosu ${ }^{50}$. Jak w konsekwencji podsumował atmosferę tamtego okresu: „duch Sulzera unosi się nad świątynią jak jaki fetysz w całej swej okazałości" ${ }^{51}$.

Zaadaptowano również Sulzerowskie kompozycje. Społeczność lwowska oczekiwała wykonywania podczas liturgii synagogalnej nowych „śpiewów chóralnych” Sulzera, Lewandowskiego i Naumbourga ${ }^{52}$. Wymagano również zmiany stylu wykonawstwa tych solowych recytatywów kantoralnych, które w liturgii pozostały, a które nie zostały zmodernizowane przez zachodnioeuropejskich reformatorów. Należało wówczas zastosować reguły, jakie przyświecały idei reformy muzycznej w ogóle: zrezygnować z melizmatów, ozdobników, popisów, skrócić i zrytmizować tradycyjne melodie. Jak wspominał Minkowski:

Także i słowa z „Magen Awot” [...] tak podobne do melodii muzułmańskich, wydobywałem z ust jak z jakiej maszyny, bez należytego wewnętrznego akcentowania. Jednym słowem posłuchałem wskazówek [...] i byłem przez cały wieczór kantorem bezwzględnie „niemieckim" ${ }^{53}$.

${ }^{47}$ Bałaban, Historia lwowskiej synagogi..., s. 41.

${ }^{48}$ Tamże, s. 30.

49 Tamże, s. 43, 106, 186.

${ }^{50}$ Tamże, s. 106-107.

51 Tamże, s. 107.

${ }_{52}$ Tamże, s. 106.

53 Tamże, s. 108. 
Opór Minkowskiego wobec wymagań środowiska lwowskiego zwiastuje krytyczną odpowiedź na reformę zachodnioeuropejską wśród Żydów centralnej i wschodniej Polski. Przyczyn odrzucenia nowej zachodnioeuropejskiej muzyki synagogalnej było kilka. Po pierwsze, od wieków społeczność żydowska obu części Europy posługiwała się odmiennym repertuarem i stylem wykonawczym, posiadała własne tradycje muzyczne kształtowane „w dialogu” z folklorem muzycznym narodów tej części Europy, którą zamieszkiwała. Dodatkowo, na te odmienne tradycje muzyczne nałożyły się teraz inne wzorce, które naśladowano, europeizując muzykę synagogalną. Różne były bowiem ideały estetyczne muzyki uprawianej w Niemczech i w Polsce tego okresu. Stąd zjadliwa uwaga Minkowskiego o „byciu kantorem niemieckim". W podobnym tonie jeszcze w $1929 \mathrm{r}$. wypowiadał się krytyk muzyczny „Nowego Dziennika” i dyrygent chóru krakowskiego Templu Izaak Lust, który o reformie muzyki synagogalnej pisał tak:

Odcięci przez długie wieki od świata zachowali swą muzykę na pierwotnym poziomie. Otwarcie bram ghetta, postawiło ich nagle wobec bogactwa technicznego muzyki europejskiej; chłonięto ją chciwie starając się zastąpić nią własną. Śpiewy synagogalne, zbyt silnie związane z rytuałem modlitwy, usiłowano przynajmniej tak zeuropeizować by straciły swój odrębny charakter; w tym celu wprowadzono do nich chóry a potem organy. Fakt, że przodowało tym ruchem Żydostwo niemieckie, rozstrzygnął o wzorze, na którem się przy tym oparło: był nim chorał protestancki. W jego ramy harmoniczne i rytmiczne starano się wtłoczyć kłócące się z nimi tworzywo tradycyjnych melodyj. Pominięto zaś bliższy im znacznie chorał gregorjański i wyrosły z niego styl polifoniczny. Było to niewątpliwie w duchu epoki rozmiłowanej w homofonji; na praktyki te wpłyną jednak niewątpliwie niezbyt szeroki horyzont muzyczny samychże adaptatorów. Nic dziwnego, że wejście tak „poprawionej” muzyki synagogalnej nie zwróciło niczyjej uwagi: pozbawiona wszelkich oryginalnych wartości ginęła ona w powodzi podobnej miernoty muzycznej ${ }^{54}$.

${ }^{54}$ Izaak Lust, $O$ muzykę żydowska, „Nowy Dziennik” (1929), nr 263, s. 11. Pisownia oryginalna. Opinia Lusta na temat zachodnioeuropejskiej reformy żydowskiej muzyki liturgicznej każe w nowy sposób spojrzeć na analogiczny proces zachodzący w Europie Wschodniej. W świetle słów dyrygenta chóru krakowskiego Templu - a więc osoby w pewnej mierze odpowiedzialnej i decydującej o przemianach repertuaru liturgicznego w jednej z wzorcowych dla dawnej Galicji społeczności postępowych - reforma wschodnioeuropejskiej muzyki synagogalnej nie mogła polegać wyłącznie na naśladowaniu kompozycji powstających na Zachodzie. Wręcz przeciwnie, krytycznie do nich ustosunkowany Lust oczekiwał zachowania wschodnioeuropejskich żydowskich tradycji muzycznych modernizowanych przy użyciu technik kompozytorskich właściwych chrześcijańskiej muzyce liturgicznej sprzed okresu reformacji i uznanych za wzorcowe podczas soboru trydenckiego, a obecnych w życiu muzycznym m.in. otaczających go wschodnioeuropejskich chrześcijan. W tym kontekście trudno oprzeć się wrażeniu, że poglądy Lusta stanowią wykładnię swego rodzaju „XX-wiecznej 
Oprócz odmienności lokalnych tradycji muzycznych niewątpliwie istotny wpływ na kierunek modernizacji muzyki synagogalnej w Galicji miały przemiany społeczne i polityczne dokonujące się w obrębie społeczności żydowskiej. Zachwyt „muzyką niemiecką” wydaje się naturalny w okresie, w którym Żydzi galicyjscy opowiadali się za proaustriackim kierunkiem asymilacji, germanizacją własnej kultury. Kiedy jednak kierunek ten zmienił się na propolski, zmodyfikowana musiała zostać również polityka kulturalna reformatorów ${ }^{55}$. Analogicznie, gdy w ostatniej dekadzie XIX w. do głosu doszło zjawisko emancypacji narodowej Żydów, duma narodowa i potrzeba promocji własnej kultury wywarły wpływ na życie muzyczne galicyjskich synagog. Dążenia do podniesienia poziomu własnej kultury muzycznej, europeizacji czy też uniwersalizacji tradycyjnego języka muzycznego, uatrakcyjnienia go w oczach nowego pokolenia, a jednocześnie zachowania własnej tożsamości (której muzyka była nośnikiem) i podkreślenia odrębności narodowej stały się programem modernizacji żydowskiej muzyki liturgicznej (i muzyki żydowskiej w ogóle) w Galicji. W okresie międzywojennym reformę postrzegano już nie tylko jako piękną i porywającą ideę, ale jako palącą konieczność wobec spostrzeżeń odnotowanych przez Izaaka Lusta: „,postępujący zanik ortodoksji stawia [Żydów] wobec dylematu zatracenia własnej kultury muzycznej lub przekształcenia jej we współczesne formy muzyki artystycznej”56.

Tym samym reformę muzyki synagogalnej w Galicji można poniekąd rozpatrywać niezależnie od niemieckich i austriackich inicjatyw. Jako dziejowa konieczność była odpowiedzią na przemiany historyczne, społeczne i polityczne, które miały inny przebieg w różnych częściach Europy. Oryginalność i przywiązanie do własnych tradycji muzycznych, modernizacja własnej kultury w obrębie środowiska polskiego i poniekąd w dialogu z nim, silna ortodoksja i poczucie dumy z żydowskiej tożsamości różniły społeczność galicyjską od niemieckiej czy austriackiej. Odmienne były też ich gusta muzyczne. Nie do pomyślenia wydaje się rezygnacja z charakterystycznego ekspresywnego stylu wschodnioeuropejskiego chazanut na rzecz niemieckiego ładu

żydowskiej kontrreformacji” postulującej zachowanie rodzimych tradycji muzycznych, choć opracowanych w sposób atrakcyjny dla współczesnego odbiorcy.

55 Zob. Tomasz Gąsowski, Między gettem a światem. Dylematy ideowe Żydów galicyjskich na przełomie XIX i XX wieku, Kraków 1996, s. 101-106; Maślak-Maciejewska, Wydarzenia patriotyczne..., s. 103-128; taż, Działalność Towarzystwa Agudas Achim i jego zwiazki z synagogami postępowymi we Lwowie i Krakowie, „Kwartalnik Historii Żydów” (2014), nr 1, s. $173-202$.

${ }^{56}$ Lust, O muzyke..., s. 11. 
formalnego, porzucenie dążenia do zawładnięcia słuchaczem i dostarczenia mu możliwości przeżycia muzycznego katharsis (dewekut) w zamian za intelektualną kontemplację porządku brzmieniowego, czytelność śpiewanego tekstu. W zakresie myśli estetycznej społeczność żydowska Galicji pozostała bliska wrażliwości muzycznej narodów słowiańskich, a jednocześnie również od nich odmienna i tę odmienność wyrażająca własnym językiem muzycznym. W ten sposób muzyka synagogalna pełniła funkcję nośnika informacji o własnej tożsamości - przede wszystkim tożsamości żydowskiej ${ }^{57}$. Jak podsumował entuzjazm lwowian po wykonaniu przez siebie tradycyjnych modlitw synagogalnych Minkowski: „Nie Niemcy i nie Polacy mojżeszowego wyznania, ale bracia moi otoczyli mnie i ściskali mi dłonie!"58.

\section{Modernizacja muzyki synagogalnej „po galicyjsku”}

Relacje Majera Bałabana jednoznacznie potwierdzają, że lwowska społeczność postępowa wprowadziła kompozycje zachodnioeuropejskich reformatorów do liturgii odprawianej w lokalnym Templu. Pewności tej nie ma w odniesieniu do Krakowa. Jak podaje Alicja Maślak-Maciejewska:

Z zachowanych bardzo nielicznych wypowiedzi postępowców na temat samej liturgii wynika, że w ich odczuciu nabożeństwo w Templu nie różniło się w zasadniczych elementach od nabożeństw w innych synagogach [...]. Różnicę stanowiły cechujące je uporządkowanie, spokój, większa elegancja, zwracanie uwagi na stosowność, decorum $^{59}$.

Na ów spokój i elegancję wpłynęła z pewnością modernizacja opracowania muzycznego liturgii. Dlatego okoliczności, takie jak: wzorowanie się na reformie wiedeńskiej, prowadzenie własnego chóru, a także brak własnych chóralnych opracowań modlitw synagogalnych, pozwalają przypuszczać, że również krakowskie środowisko postępowe korzystało w liturgii z kompozycji Sulzera, Lewandowskiego i Naumbourga, przynajmniej do czasu wypracowania wschodnioeuropejskich aranżacji modlitw synagogalnych. Te ostatnie mogły nawet być dziełem (nigdy niepublikowanym) lokalnego kantora lub dyrygenta służącym wyłącznie zatrudniającej go społeczności.

57 Tak jak były nim „niemieckie kompozycje chóralne” germanizującej się inteligencji lwowskiej czy pieśń „Boże, coś Judę” wykonywana w propolskim środowisku członków „Agudas Achim”. Por. Bałaban, Historia lwowskiej synagogi..., s. 105-109; Maślak-Maciejewska, Działalność Towarzystwa Agudas Achim..., s. 199-200.

${ }^{58}$ Bałaban, Historia lwowskiej synagogi..., s. 109.

${ }^{59}$ Maślak-Maciejewska, Modlili się w Templu..., s. 245. 
Stąd trudno choćby przypuszczać, jaki był zakres wykorzystania zachodnioeuropejskiego repertuaru w Krakowie.

W okresie międzywojennym z pewnością pojawiał się on często na uroczystościach świątecznych organizowanych przez społeczności postępowe. Kompozycje Sulzera, Lewandowskiego, Naumbourga wykonywano podczas koncertów chanukowych wraz z repertuarem klasycznym oraz utworami kantorów i kompozytorów wschodnioeuropejskich: Dawida Weintrauba, Abrahama Dunajewskiego, Samuela Almana, Dawida Nowakowskiego, a także twórców żydowskiej szkoły narodowej w muzyce ${ }^{60}$. Prezentowano je również na koncertach muzyki religijnej odbywających się w przestrzeni sakralnej i świeckiej, zamkniętej oraz publicznej, w tym podczas koncertów muzyki żydowskiej na antenie lwowskiej i krakowskiej radiostacji ${ }^{61}$. Występowała tu już nie jako muzyka użytkowa, liturgiczna, ale jako muzyka artystyczna, koncertowa, wyrwana z naturalnego kontekstu. Jej nowym przeznaczeniem było udowodnienie nieżydowskiemu słuchaczowi przynależności nowoczesnej kultury żydowskiej do kręgu europejskiego. Wkrótce też - w świetle statystyk - dla wielu członków galicyjskiej społeczności żydowskiej autentyczna żydowska muzyka ludowa stała się „obca”. Przestała być „ich” muzyką ${ }^{62}$.

Abstrahując od samego wykorzystania zachodnioeuropejskiego repertuaru, wyraźne piętno na życiu muzycznym galicyjskiej ortodoksji odcisnęła z pewnością sama idea modernizacji muzyki synagogalnej, aktualna myśl estetyczna epoki przyznająca muzyce najwyższe miejsce wśród sztuk i uwalniająca ją z wszelkich funkcji służebnych w życiu społecznym. Nie tylko do synagog postępowych, ale i do wielu synagog ortodoksyjnych

${ }^{60}$ Archiwum Narodowe w Krakowie, Archiwum Związku Żydowskich Stowarzyszeń Humanitarnych B'nei B'rith w Rzeczypospolitej Polskiej w Krakowie, zesp. 557, Związek Żydowskich Stowarzyszeń Humanitarnych BB w Rzeczypospolitej Polskiej w Krakowie z lat 1924-1938, BB 134, s. 41; Kronika. Nadkantor p. Dywiński..., „Nowy Dziennik” (1918), nr 141, s. 4; Plohn, Koncert synagogalny..., s. 5; Koncert chanukowy, „Chwila” (1922), nr 1368, s. 5; Wiadomości z kraju. List z Przemyśla. Wieczór pieśni hebrajskiej, „Nowy Dziennik” (1926), nr 35, s. 7; Alfred Plohn, Chór żydowski, „Chwila” (1931), nr 4325, s. 7; Koncert muzyki synagogalnej..., „Nowy Dziennik” (1931), nr 58, s. 4; Alfred Plohn, Żydowskie Towarzystwo Artystyczno-Literackie, „Chwila” (1932), nr 4745, s. 9; Wieczór Żyd[owskiego] Tow [arzystwa] Lit[eracko] Art [ystycznego] we Lwowie, „Chwila” (1932), nr 4688, s. 13; Koncert chanukowy..., „Chwila” (1933), nr 5288, s. 16.

${ }^{61}$ Koncert muzyki synagogalnej i pieśni żyd[owskiej] w Polskiem Radjo, „Chwila” (1932), nr 4927, s. 15; Pieśń żydowska w radjo, „Nowy Dziennik” (1933), nr 20, s. 6.

${ }^{62}$ Czesław Brzoza, Żydowska mozaika polityczna w Polsce 1917-1927 (wybór dokumentów), Kraków 2003, s. 63-130, 137-139; Gąsowski, Między gettem a światem..., s. 85-135. 
uczęszczano, by słuchać muzyki. Mieli tego świadomość kantorzy i chóry synagogalne, które nagminnie prowadziły tam „prawdziwe śpiewacze wojny, w których chazan i chór walczyli o laur" ${ }^{33}$. Z wojen tych korzystali „słuchacze”. W prasie międzywojennej pojawiły się recenzje (!) nabożeństw świątecznych ${ }^{64}$. W 1937 r. sprawozdawca muzyczny jidyszowego tygodnika „Di Post” w Krakowie w sposób następujący relacjonował przebieg obchodów święta Rosz ha-Szana w lokalnych synagogach:

Rzadko można spotkać dwie osoby, które tak samo odmawiają nusach [...], ponieważ już od dawna znana jest prawda, że „styl człowieka jest odbiciem jego charakteru". Zatem rzadko też spotyka się dwóch chazanów lub bal-tfila, którzy śpiewają lub odmawiają ,zgodnie z jednymi i tymi samymi zaleceniami”. I to nam potwierdza nasz spacer po krakowskich synagogach podczas Rosz Haszone, które wypełnione były wówczas modlitwą, choć nie zawsze pobożnością...

W Starej Synagodze chazan Goldberg słodko i lwim głosem, który posiada w całej skali, jak też w koloraturze i falsecie, modlił się serdecznie z towarzyszeniem dobrze zestrojonego chóru. Z licznym, dobrze przeszkolonym chórem Synagogi Kupa wystąpił chazan Kojfman, który posiadł sztukę łączenia śpiewu i recytacji nusach w nowym, chwytającym za serce kantorskim stylu, który stoi, jak u chazana Goldberga, pod znakiem Lejzerkowego dziedzictwa muzycznego.

W synagodze Ahawas Raim zaprezentował się ze swoim chórem wybitny, młody, utalentowany chazan Mandl, którego modlitwa jest syntezą nowego i starego stylu kantorskiego, w których zawarł też znaczną ilość elementów folkloru, co nadaje jego interpretacjom wyjątkowego uroku. Jednak najbardziej nowoczesnym wśród krakowskich chazanów jest bez wątpienia profesor Baruch Sperber (Bugner szul), który pociąga zarówno swoim bohaterskim tenorem, jak i oryginalnym wyodrębnianiem każdego słowa i każdego wersetu, a przede wszystkim swoim paroksytonicznym akcentowaniem, w którym jego uczuciowy, słodki śpiew i mowa prowadzą do autentycznej przemiany [oryg. tikun].

${ }^{63}$ A. Meloman, Di banejung fun di Lejzerkes muzikaliszer Chanuke tradicje, „Di Post” (1937), nr 14, s. 7. Lejzerkowa tradycja - tak określano popularną zarówno w kręgach ortodoksyjnych, jak i postępowych praktykę wykonywania podczas koncertów świątecznych kompozycji Eliezera Goldberga, uwielbianego w Krakowie, a zmarłego tu w 1922 r. kantora, kompozytora i dyrygenta synagogi Kupa.

${ }^{64}$ Recenzja jest gatunkiem publicystycznym zarezerwowanym dla oceny koncertu czy dowolnej świeckiej formy życia muzycznego, której funkcją jest dostarczenie słuchaczowi wrażeń estetycznych. Nabożeństwa - jako wydarzenia o charakterze religijnym, rozbudowana forma modlitwy - z założenia nie podlegają ocenie estetycznej. I choć w praktyce wyznawcy różnych religii tej oceny dokonują, decydując się na uczestnictwo w liturgii tam, gdzie jej kształt odpowiada m.in. ich gustom estetycznym, to jednak taka zinstytucjonalizowana forma oceny estetyki nabożeństwa jest z perspektywy religijnej bezzasadna i każe postawić pytanie o dokonującą się w myśli sankcjonującej ją społeczności desakralizację wydarzenia religijnego. 
Ładne rozmodlenie i piękny śpiew spotykamy również u chazanów Mandlbojma (Cypres), Armera (Deiches) i kantora Szechtera (Tempel). Bal-tfilowemu nusachowi wierni są: szojchet Rubinsztejn (reb Izaak Jekels) i reb Mosze Mejer Goldklang (Synagoga Wysoka). Obie synagogi nie posiadają regularnego, pełnogłosowego chóru ${ }^{65}$.

Ten krótki przegląd oprawy muzycznej noworocznych nabożeństw w krakowskich synagogach zaskakuje w kilku miejscach. Po pierwsze wskazuje na „nieortodoksyjny” stosunek społeczności ortodoksyjnej do muzyki liturgicznej, w praktyce bowiem wartości estetyczne przedłożono ponad troskę o pobożność. Po drugie dowodzi wpływu nowoczesnego stylu śpiewu synagogalnego na tradycyjną sztukę kantoralną. Według sprawozdawcy niemal każdy z wymienionych chazanów łączył w swoim śpiewie „nowy” i „stary” styl kantorski. Sam recenzent nie kryje też własnych preferencji wobec „nowoczesności”. Po trzecie, tylko dwie z wymienionych synagog krakowskich nie miały własnego chóru. Synagoga Stara, Kupa, Ahawas Raim, Bugner szul, a prawdopodobnie także domy modlitwy Cypresa i Deichesa posiadały „pełnogłosowe” (czyli czterogłosowe) zespoły chłopięco-męskie. Na przykład - chór krakowskiej synagogi Starej w 1938 r. składał się z 24 osób ${ }^{66}$.

Oczywiście nie mogło być mowy o użyciu instrumentów w synagogach ortodoksyjnych. Podczas wielkich świąt nie stosowały ich nawet społeczności postępowe. Rezygnowały one także z użycia jakichkolwiek instrumentów w pozostałe dni świąteczne ze względu na możliwość naruszenia reguł halachy. Restrykcje religijne generalnie wytworzyły atmosferę niechęci do wykonawstwa muzyki instrumentalnej w synagodze. Mimo to zmiana przyzwyczajeń („tradycji”) dokonywała się tam, gdzie nie powodowała naruszenia Prawa. Po przełamaniu pierwszego oporu wobec świeckiego kształcenia muzycznego na dworze chasydów w Czortkowie nastąpiły dalsze przemiany: „Dwór w Czortkowie zezwolił na występ miejskiej orkiestry dętej w synagodze. To był wielki sukces. Po raz pierwszy w historii czortkowskiego dworu miejska orkiestra zagrała podczas koncertu chanukowego w synagodze" ${ }^{67}$. W 1937 r. w krakowskiej synagodze Kupa

${ }^{65}$ A. Meloman, Rosz Haszone in di krokewer szuln, „Di Post” (1937), nr 2, s. 7.

${ }^{66}$ Chanuka w Starej Bożnicy..., „Nowy Dziennik” (1938), nr 346, s. 17.

${ }^{67}$ Cwi Orensztejn, Czortkow we-ha-musika ha-jehudit, [w:] Sefer jizkor le-hanecahat kedoszej kehilat Czortkow, red. Jeszajahu Austridan, Hajfa-Tel Awiw 1967, s. 155. Wydarzenie musiało mieć miejsce bisko przełomu XIX i XX w. Autor wspomnień wydanych w 1967 r., który był nauczycielem muzyki w czortkowskiej szkole żydowskiej otwartej w 1904 r., zaznacza, że je pamięta. 
zorganizowano z kolei koncert chanukowy, na którym prócz kantora tej synagogi, Samuela Kojfmana, wystąpił chór i orkiestra pod dyrekcją innego ortodoksyjnego kantora, a jednocześnie kierownika muzycznego lokalnego Teatru Żydowskiego, Barucha Sperbera ${ }^{68}$.

Analiza zachowanych relacji, dokumentów, notatek prasowych, zapisów nutowych nie pozostawia wątpliwości co do tego, że reforma muzyki synagogalnej w Galicji dokonywała się również w środowisku ortodoksyjnym. Tutaj też rozkwitła najpełniej, bo choć impuls historyczny wyszedł ze środowiska niemieckiego, następnie - dość wcześnie - galicyjscy Żydzi postępowi zaadaptowali twórczość reformatorów i jako pierwsi postulowali przemiany własnych tradycji muzycznych, oni też jako nowa inteligencja żydowska najprędzej posiedli narzędzia (wykształcenie muzyczne) do przeprowadzenia reformy, to jednak nie jest znany żaden kompozytor muzyki liturgicznej z galicyjskich kręgów postępowych. Odwrotnie, galicyjscy modernizatorzy XX w. promowali twórczość współczesnych im kantorów ortodoksyjnych. Ten sam Izaak Lust, który krytykował „miernotę muzyczną" napływającą z Europy Zachodniej, wykonywał z chórem synagogi postępowej w Krakowie kompozycje Eliezera Goldberga, kantora ortodoksyjnej synagogi Kupa (mimo iż ten nie miał żadnego wykształcenia muzycznego i konsekwentnie korzystał z lokalnej tradycji ludowej).

\section{Perły galicyjskiej reformy: kompozycje Barucha Schorra, Barucha Kinstlera i Eliezera Goldberga}

Analiza międzywojennej galicyjskiej prasy żydowskiej wskazuje na niesłabnącą w tym okresie popularność kompozycji trzech kantorów przełomu wieku XIX i XX: Barucha Schorra, Barucha Kinstlera i Eliezera Goldberga. Ich opracowania modlitw synagogalnych cieszyły się - a niektóre nadal się cieszą - zainteresowaniem kolejnych pokoleń wykonawców żydowskiej muzyki liturgicznej. Wszyscy komponowali z przeznaczeniem dla solisty i czterogłosowego chóru, wszyscy korzystali również z tradycyjnych melodii Europy Środkowo-Wschodniej. Każdy zachował charakterystyczny, silnie emocjonalny styl wschodnioeuropejskiego chazanut, posiadał też indywidualny i łatwo rozpoznawalny styl kompozycji.

68 Meloman, Di banejung..., s. 7. 
Baruch Schorr jest najstarszym kompozytorem w omawianym gronie. Urodził się we Lwowie w 1823 r. ${ }^{69}$ Kształcił się u kantora Becalela Schlusingera w Odessie (znanego też jako Becalel Odesser) i Chaima Jeruchama Blindmana (zwanego również Jerucham ha-Katan) w Tarnopolu. Następnie objął posady kantorskie w Jassach (Rumunia), Chocimiu, Kamieńcu Podolskim i Budapeszcie. W 1859 r. powrócił do Lwowa, gdzie do końca życia (z pięcioletnią przerwą, kiedy wyjechał do Nowego Jorku) był kantorem i kompozytorem synagogi Miejskiej. Spośród napisanych dla niej kompozycji zachował się zbiór opracowań melodii liturgicznych na wielkie święta, wydany przez syna Barucha, Izraela, w USA pod tytułem N'ginoth Baruch Schorr ${ }^{70}$. Podobnie jak inne dzieła Schorra miał on być wzorowany na operach Jehudy Halevy'ego i Giacomo Meyerbeera ${ }^{71}$. Schorr był zainteresowany tym gatunkiem muzycznym, co potwierdza również wystawienie w 1890 r. przez lwowski Teatr Żydowski jego własnej operetki Szimszon ha-gibor.

Styl kompozytorski Schorra rzeczywiście jest zbieżny ze stylem epoki. W swojej twórczości synagogalnej Schorr upodabnia się do Sulzera - skraca, rytmizuje, upraszcza partie kantoralne. Rezygnuje z nadmiaru ornamentów. Harmonizuje tradycyjne melodie liturgiczne na czterogłosowy zespół wokalny, posługując się przy tym szeroko wykorzystywaną w muzyce chóralnej romantyzmu, w tym w niemieckiej muzyce religijnej i francuskiej operze, fakturą homofoniczną. Pozostaje przy tym jednak silnie sugestywny i ekspresywny. Nie ogranicza koloratury kantora tam,

${ }^{69}$ Zob. Elias Zaludkowski, Kultur-treger fun der jidiszer liturgie: historisz-biografiszer iberblik iber chazones, chazonim un diriżorn, Detroit 1930, s. 88-93; Edelman, Discovering Jewish Music..., s. 65. Zachowane dokumenty archiwalne podają tę datę w wątpliwość. W metrykach zgonów odnotowano, że Schorr zmarł 7 kwietnia 1904 r. w wieku 72 lat, co wskazywałoby na datę urodzenia w 1832 r., a nie 1823 r. Zob. Archiwum Główne Akt Dawnych [dalej: AGAD], Księgi metrykalne wyznania mojżeszowego, zesp. 300, Księga metrykalna zgonów, gm. Lwów, pow. Lwów, 1904, sygn. 2436, s. 29, akt nr 289. Z drugiej strony wykaz z księgi urodzeń za 1832 r. nie odnotowuje Barucha Schorra, podczas gdy pojawia się on we wtóropisie księgi urodzeń z 1823 r. Zob. AGAD, Księgi metrykalne wyznania mojżeszowego, zesp. 300, Księga metrykalna urodzeń, t. 5, gm. Lwów, pow. Lwów (1822-1828), sygn. 515, s. 15. Z kolei w pośmiertnym wspomnieniu Schorra zamieszczonym przez katowickiego kantora Szymona Singera w „Israelitische Wochenschrift” (1904), nr 19, s. 266-267, jego autor podał, że zmarły w 1904 r. Schorr przeżył 84 lata (por. Aron Friedmann, Lebensbilder berühmter Kantoren 2. Zum 100. Geburtstage des Königlichen Musikdirektors Professor weiland Louis Lewandowski, Berlin 1921, s. 79-82).

${ }^{70}$ N'ginoth Baruch Schorr: Complete Service, According to the Traditional Ritual for New Year and Day of Atonement, red. Israel Schorr, New York 1906. Zbiór ten był wielokrotnie wznawiany; w dalszej części artykułu cytaty oparte są na wydaniu z roku 1952.

${ }^{71}$ Alfred Plohn, Muzyka we Lwowie a Żydzi, „Muzykalia XIII. Judaica 4” (maj 2012), s. 15, http://demusica.edu.pl/muzykalia-xiii-judaica-4/ [dostęp: 23 października 2018]. 
gdzie zależy mu na podkreśleniu wagi słów. W modlitwie wieczornej na Rosz ha-Szana i Jom Kippur Wahawoscho al tosir / We-ahawatecha al tasir ${ }^{72}$ wprowadza ją na słowach: kochasz swój lud, Izrael, upominając się w ten sposób u Stwórcy o miłosierdzie dla ludu wybranego w dniu Jego sądu nad światem ${ }^{73}$.

Opracowanie partii chóralnych w kompozycjach Schorra zdradza też jego silne zakorzenienie w tradycji muzycznej synagog wschodnioeuropejskich. Często pojawia się tam śpiew responsorialny, gdzie kantor intonuje wezwania podejmowane następnie przez chór. Dzieje się tak na przykład w kompozycji Wehakojanim / We-ha-kochanim ${ }^{74}$. Niekiedy recytatyw kantora zamyka krótka akordowa partia chóru naśladująca spontaniczne odpowiedzi modlaccych się w ortodoksyjnej synagodze. Pojawiają się też odcinki opracowane jako paralelne pochody sekstowe, naśladujące tradycyjny śpiew meszorerów, gdzie sopran dublował partię kantora w tercjach lub sekstach, a bas prowadził podstawę harmoniczną. Te sposoby kompozycji widoczne są chociażby w opracowaniu muzycznym modlitwy Hajem haras ojlem / Ha-jom harat olam ${ }^{75}$. Według relacji Eliasa Zaludkowskiego zdarzało się, że z powodu zakazu używania instrumentów w liturgii synagogalnej Schorr - podobnie jak inni kantorzy-kompozytorzy - traktował zespół wokalny jak orkiestrę. Chórzyści nucili wówczas pozbawione tekstu słownego melodie, starając się naśladować brzmienie zespołu dętego ${ }^{76}$.

Tradycyjny charakter kompozycji synagogalnych Schorra został zachowany również dzięki wykorzystaniu w warstwie melodycznej formuł charakterystycznych dla modi synagogalnych ${ }^{77}$. Szczególnie często w muzyce kantorów Europy Środkowo-Wschodniej pojawiają się modi i skale wykorzystujące interwał sekundy zwiększonej, tj. modus Ahawa Raba oraz skala ukraińsko-dorycka. Obie jednak stanowiły istotne wyzwanie w zakresie harmonizacji. Podobnie jak wszyscy kantorzy-kompozytorzy XIX w. starający się zeuropeizować brzmienie melodii synagogalnych również Schorr musiał znaleźć sposób, w jaki można połączyć dwa różne

72 Tytuły utworów (będące zwykle incipitem modlitwy) podaję najpierw w transkrypcji wymowy aszkenazyjskiej, w takiej wersji były bowiem śpiewane i aby zachowana była zgodność rozdysponowania sylab między kolejnymi dźwiękami melodii, a obok podaję wymowę sefardyjską.

${ }_{73}$ Zob. N'ginoth Baruch Schorr..., s. 33.

${ }^{74}$ Tamże, s. 231-234.

75 Tamże, s. 145.

76 Zaludkowski, Kultur-treger..., s. 92.

77 Omówienie modi synagogalnych w: Charles Davidson, Immunim Benusah Hatefillah I: A Study Text and Workbook for the Jewish Prayer Modes, Elkins Park 1996. 
systemy muzyczne. Rozwiązał ten problem metodą ,połowiczną” - traktował dźwięki obce systemowi funkcyjnemu jako przejściowe i unikał ich harmonizacji bądź łamał zasady harmoniki europejskiej i stosował na przykład równoległe pochody interwałowe i akordowe. Jego kompozycje chóralne są z konieczności niestabilne tonalnie, oscylują między tonalnością dur-moll a chóralnym unisono fragmentów modalnych. Pewną niezręczność stanowią jego kadencje dominantowo-toniczne i częste użycie tercji pikardyjskiej w ostatnim współbrzmieniu kompozycji, obie charakterystyczne dla muzyki europejskiej, a jednocześnie zakłócające koloryt brzmienia muzyki synagogalnej.

$\mathrm{Z}$ muzyki europejskiej Schorr przejął symetryczne formy muzyczne $\mathrm{z}$ ich budową okresową. Psalmodia w jego opracowaniu zamieniła się w pieśń. Wykorzystując zwrotkową budowę Psalmu 24, Schorr opracował go dwuczęściowo - jako formę AA'. Rozbudowany pijut Owinu Malkejnu / Awinu Malkenu również opracował dwuczęściowo. Połączył tu technikę antyfonalną z formą repryzową, tworząc model, który można opisać jako: A[abab...]B[cdcd...]A'[a]. W najdłuższych opracowaniach modlitw brakuje jedynie - z perspektywy europejskiego melomana tamtych czasów - motywów ujednolicających całość, powtarzających się regularnie tematów, które wskazywałyby na muzyczną jedność wieloczęściowych kompozycji liturgicznych. Ich brak może wynikać z zamysłu harmonizacji tradycyjnych melodii liturgicznych, które tych motywów nie miały. Choć zarazem wykorzystanie tradycyjnych melodii sprawia, że w opracowaniach Schorra pojawiają się tzw. motywy uniwersalne, czyli krótkie formuły melodyczne, których powtarzalność zwraca uwagę słuchacza. Niektóre $\mathrm{z}$ nich pełnią wyłącznie funkcję strukturalną, pojawiając się przypadkowo w dowolnych miejscach opracowania tekstu słownego. Inne - na wzór wagnerowskich „leitmotivów” - służą przypomnieniu treści, którym towarzyszyły poprzednio. $Z$ tej perspektywy identyczność incipitów modlitw Kowedu / Kewodo i Kdusze / Kedusza w zbiorze Schorra można interpretować jako zabieg uwypuklający doniosłość obu momentów liturgii: aklamacji aniołów trzykrotnie obwieszczających świętość Boga oraz wspomnienie obyczaju dorocznego wypowiadania Bożego Imienia przez arcykapłana na dziedzińcu świątynnym.

$\mathrm{Z}$ problemem harmonizacji modalnej melodyki doskonale poradził sobie kantor lwowskiej synagogi Przedmiejskiej, Baruch Kinstler. W rzeczywistości nazywał się Baruch Pogacz i urodził się w 1846 r. w Szepetówce na Wołyniu. W tajemnicy przed ojcem kształcił się u miejskiego chazana, 
a gdy był już pełnoletni i żonaty, zdecydował się wyjechać do Berdyczowa, by kontynuować naukę u Jeruchama ha-Katana. Wkrótce też został kantorem w Starym Konstantynowie, a w 1890 r. we Lwowie. Od dwudziestego drugiego roku życia komponował na potrzeby synagogi. Kunsztowność jego dzieł sprawiła, że we Lwowie nadano mu przezwisko „kinstler”, czyli „artysta”. Zajmował się też kształceniem muzycznym. Do grona jego uczniów należeli kantorzy: Mejer Zajfert (USA), Grob (Wiedeń), Bernard Lwowicz (Lwów), Jehoszua Alter (brat hanowerskiego kantora Izraela Altera), a także dyrygent lwowskiej opery Josef Lerner. Dyrygentem został też jego syn, Becalel, który kierował chórem lwowskiego, a później tarnowskiego Templu ${ }^{78}$.

Twórczość Kinstlera stanowi syntezę wschodnioeuropejskiego chazanut z europejskimi technikami kompozycji, przy czym wyróżnia ją posługiwanie się stylem dawnej polifonii chóralnej a cappella ${ }^{79}$. Sięgnięcie po europejski wzorzec harmonizacji melodyki modalnej rozwiązało trapiący ówczesnych kompozytorów żydowskich problem zastosowania młodszych historycznie praw harmoniki funkcyjnej w wielogłosowym opracowaniu melodii opartych na modi synagogalnych. Kinstler po prostu zrealizował teoretyczny postulat wyrażony na łamach prasy krakowskiej przez Izaaka Lusta (choć zrobił to znacznie wcześniej). Dzięki temu rozwiązaniu w swoich kompozycjach dokonywał swobodnych modulacji, łącząc nawet odcinki oparte na skalach dur-moll i tradycyjnych modi (Ki keszimcho / Ki ke-szimcha). Nie był też zmuszony do modyfikowania dawnych melodii, pozostawiając w nich rozpoznawalne komórki melodyczne, którymi posługiwał się na wzór wariacyjnego opracowania bliskowschodnich makamat (np. w Ki chilucse ( Ki chilacta). W obu wspomnianych kompozycjach pozostawił też silnie ekspresyjną i bogato ornamentowaną partię kantora wykonywaną solo.

Jego kompozycje budowane są segmentowo. Kolejne fragmenty opracowania muzycznego podporządkowane są budowie i treści tekstu słownego zgodnie z ideałem estetycznym muzyki synagogalnej. Kinstler wprowadza między nimi kontrasty, posługując się różnymi skalami, trybami, rejestrami, metrum, typami rytmiki, faktury, różnorodnymi technikami kompozytorskimi i obsadami. Każdy z tych parametrów dobierany jest tak, by służyć wzmocnieniu ekspresji tekstu słownego. Hymn Keser / Keter otwiera

${ }_{78}$ Baruch Kinstler, „Di Chazonim Welt” (1934), nr 11, s. 18-19.

${ }^{79}$ Omówione w niniejszym tekście kompozycje przechowywane są w archiwum YIVO Institute for Jewish Research w Nowym Jorku: YIVO Archives, Sholem Perlmutter's Collection, RG 289, Baruch Kunstler - Korus mekhomer, folder 589. 
techniką nota contra notam, stosując pełne akordowe brzmienie. $\mathrm{W}$ ten sposób obrazuje oddawanie czci Bogu przez chóry anielskie na wysokości. Następnie wprowadza imitacje czołowe, które odmalowują dołączanie do aniołów kolejnych rzesz czcicieli spośród ludzi. Akordowe piony w dalszym przebiegu kompozycji można interpretować jako symbol jedności „powtarzających za prorokami”, a pojawiające się tuż po nich rozdrobnione wartości rytmiczne jako ilustrację zamieszania wśród „wołających do siebie”. Z „chaosem” kontrastuje stanowcze trzykrotne obwieszczenie świętości Boga w symbolicznym metrum 3/4. Ostatni zachowany fragment tej kompozycji utrzymany jest w stylistyce kołysanki, której kantylenowa melodyka oraz jednostajność rytmiczna i harmoniczna wyrażają harmonię świata zarządzanego przez Boga.

$\mathrm{Z}$ muzyki europejskiej Kinstler przejmuje też figury retoryczno-muzyczne. Jest to wyraźne odejście od estetyki tradycyjnej muzyki synagogalnej, w której utrwalił się bezpośredni, ekspresyjny, emocjonalny charakter opracowania muzycznego tekstu słownego. Tak wyrażona symbolika stanowiła domenę chrześcijańskiej muzyki artystycznej epoki baroku, a według Plohna właśnie na twórczości Bacha i Haendla miał się Kinstler wzorować ${ }^{80}$. Same figury retoryczno-muzyczne najszerzej muzyk wykorzystał w opracowaniu tekstu Ki keszimcho / Ki ke-szimcha. Zilustrował w nim muzycznie eksklamacje na cześć Boga odmalowane za pomocą wznoszących się drobnonutowych pochodów melodycznych, powrót grzesznika - wprowadzając opadające sekwencje triol, kruchość ludzkiego żywota porównanego w tekście do prochu, odłamku, więdnącej trawy, blednącego kwiatu, niknącego cienia, rozmywającej się chmury, wiejącego wiatru, ulotnego marzenia wyraził przy użyciu krótkich, niekiedy gwałtownie zrywanych fraz melodycznych, natomiast wieńczące tekst słowny obwieszczenie ponadczasowej władzy Boga nad Jego ludem podkreślił zamykającymi kompozycję uroczystymi pionami akordowymi.

Podobnie jak Schorr również Kinstler w sposób naturalny przemawia tradycyjnym językiem muzycznym wschodnioeuropejskiej synagogi. W Ki keszimcho / Ki ke-szimcha dubluje w tercjach melodię kantora i powierza jej wykonanie sopranowi, natomiast bas prowadzi w tym czasie podstawę harmoniczną. W tej samej kompozycji, a także w zachowanym Koruc mechomer / Karut mechomer, Kinstler naśladuje w partii chóru gwałtowne odpowiedzi modlących się, którzy w ten sposób czynią wypowiedzianą

${ }^{80}$ Plohn, Muzyka we Lwowie..., s. 14. 
przez kantora w ich imieniu modlitwę - swoją własną. Wśród wykorzystanych technik kompozytorskich pojawiają się imitacje (Keser / Keter), dialogi grup głosowych (Ki chilucse / Ki chilacta, Koruc mechomer / Karut mechomer), technika nota contra notam (Keser / Keter). Jeszcze wyższy stopień zaawansowania technicznego znajdujemy w modlitwach Kojenejcho / Kohanejcha oraz Ejc chajim / Ec chajim, gdzie kompozytor przeprowadza przez poszczególne głosy chóru kolejno dwa różne tematy, a następnie nakłada je na siebie, tworząc stretto. Gdy weźmiemy pod uwagę tradycyjne wykształcenie muzyczne Kinstlera, musimy dojść do wniosku, że jego twórczość jest imponująca. Jest też fascynująca z pozamuzycznego punktu widzenia jako przełamanie dotychczasowej opozycji, która wykluczała podobieństwa między muzyką liturgiczną Żydów i chrześcijan.

Ulubionym kantorem-kompozytorem społeczności krakowskiej przez ponad sześćdziesiąt lat pozostawał Eliezer Goldberg. Urodził się w $1843 \mathrm{r}$. w Wiśniowcu (koło Krzmieńca) na Wołyniu. Ojciec zabronił mu kształcić się muzycznie, mimo to w wieku dwudziestu lat Goldberg został kantorem w swoim rodzinnym mieście. Doceniony przez rodzimą społeczność, wkrótce został kantorem w Brodach, Złoczowie i Jarosławiu, gdzie jego talent muzyczny zyskał rozgłos w całej Galicji. Stamtąd zaproszono go do Krakowa. W 1879 r. został kantorem synagogi Kupa, z którą był związany przez kolejnych czterdzieści pięć lat. Z zachowanego biogramu Goldberga autorstwa jego najwierniejszego ucznia, Barucha Sperbera, wynika, że to nie talent śpiewaczy był przyczyną, dla której tyle galicyjskich synagog zabiegało o tego kantora, ale jego półtora tysiąca kompozycji liturgicznych. Jak pisał Sperber:

nie posiadał odpowiedniego materiału głosowego, ale zachwycał świat swoimi pełnymi uczucia modlitwami i melodiami [...] niezliczonymi kompozycjami na Szabat, trzy święta pielgrzymie czy Straszne Dni, jak również wspaniałymi śpiewami chanukowymi - koncertami na chór i orkiestrę, które przyciągały tysiące melomanów ${ }^{81}$.

Z tego powodu zapewne Goldberg ograniczał rolę partii kantoralnych w swoich kompozycjach. Te, które się w nich pojawiają, są tradycyjnie wschodnioeuropejskie: bogato ornamentowane, z licznymi powtórzeniami słów, mają charakter popisowy (Riszon imacto / Riszon imacta ${ }^{82}$ ). Niektóre

${ }^{81}$ Baruch Sperber, Eliezer Goldberg, „Di Post” (1926), nr 13, s. 3.

82 Akiva Zimmermann, B'ron Yachad: Essays, Research and Notes on Hazzanut and Jewish Music, Tel Aviv 1988, s. 13-17 (appendix). 
sprawiają wrażenie wiernego zapisu kantoralnych improwizacji (Wekal baej ojlem / We-kal baej olam ${ }^{83}$ ). Oparte są głównie na skalach dur-moll oraz ludowej frejgisz, co wynika ze źródeł Goldbergowskich inspiracji, którymi często były chasydzkie melodie ludowe z Europy Środkowo-Wschodniej. Generalnie jednak Goldberg powierza prowadzenie modlitwy chórowi, na który przeznaczona jest większość jego muzycznych opracowań tekstów liturgicznych i modlitewnych.

Przykładem opracowania tradycyjnych melodii chasydzkich są kompozycje Ejn kicwe / Ejn kicwa oraz Sisu wesimchu / Sisu we-simchu wyróżniające się żywym charakterem i marszową rytmiką. Linii melodycznej towarzyszy akordowy akompaniament urozmaicany imitacjami przeprowadzanymi w kolejnych głosach chóru. Dodatkowo w Ejn kicwe / Ejn kicwa kompozytor zdaje się naśladować orkiestrę z charakterystycznym „werblem” w partii tenorów i basów. Homofoniczna faktura i hymniczny charakter cechuje opracowanie Psalmu 24, Seu szeorim / Seu szearim, które kompozytor wykorzystuje do uroczystego obwieszczenia przybycia Króla Chwały. Innym ciekawym przykładem z twórczości krakowskiego kompozytora jest kompozycja Wekol baej ojlem / We-kol ba-ej olam wzorowana na śpiewie Kościoła wschodniego z ornamentowaną, figuracyjną, ekspresyjną partią solisty rozwijającą się na tle kwintowego burdonu chóru.

Do swoich kompozycji Goldberg wprowadza również imitacje, responsoria, podobnie jak Schorr i Kinstler naśladuje gwałtowny, spontaniczny i bezpośredni charakter modlitw synagog ortodoksyjnych. Korzysta też $\mathrm{z}$ technik bardziej wyrafinowanych. W opracowaniu muzycznym Psalmu 114, Becajs Isroel / Be-cet Jisrael, używa figur retoryczno-muzycznych. Za pomocą fanfarowych pionów akordowych obwieszcza Boże panowanie nad Izraelem; serią krótkich falujących motywów melodycznych odmalowuje obraz cofającego się morza i Jordanu. Chromatyczne wstępujące pochody melodyczne ilustrują „góry podskakujące jak barany”, a opadające tercje w zstępujących pochodach sekwencyjnych - „pagórki podskakujące jak jagnięta" " 4 . Przemienienie skały w jezioro wyrażone zostało muzycznie za pomocą krótkiego, falistego, schromatyzowanego motywu melodycznego, po którym gwałtowne opadanie linii melodycznej symbolizuje wypłynięcie wody ze skały. Ostatni obraz naszkicowany przez psalmistę: ziemi drżącej

${ }^{83}$ Omawiane w niniejszym artykule kompozycje Eliezera Goldberga przechowywane są w zbiorach Biblioteki Narodowej Izraela w Jerozolimie. Za ich udostępnienie dziękuję Dyrektor Działu Muzycznego, Gili Flam.

${ }^{84}$ Cyt. za: Psalmy, thum. Izaak Cylkow, Warszawa 1883, s. 333. 
przed obliczem Boga, Goldberg ilustruje muzycznie, używając niestabilnej chromatyki, nieregularnej rytmiki i „niepokojących” niskich rejestrów.

Kompozycje Goldberga, w zgodzie z tradycją synagogalną i podobnie jak dawna europejska wielogłosowa religijna muzyka artystyczna, budowane są segmentowo. Dzięki temu możliwe jest odzwierciedlenie w muzyce obrazów i emocji zawartych w tekście słownym, sugerowanych przez tekst bądź rodzących się pod wpływem rozważań jego treści. W opracowaniu muzycznym tekstu Wekal baej ojlem / We-kal baej olam pojawiają się fragmenty przypominające „bramy” chasydzkich nigunów. Są to kwartowe i kwintowe skoki wstrzymujące rozwój narracji muzycznej i wprowadzające w kolejny etap kontemplacji. Podobnie i tutaj po pojawieniu się „bram” następuje ożywienie, charakterystyczne dla Goldberga wprowadzenie rytmiki triolowej w celu stworzenia napięcia i zbudowania kulminacji utworu.

Mimo śmierci Goldberga w 1920 r. jego twórczość nie została zapomniana przez krakowian. W 1937 r. na łamach krakowskiej prasy powszechnie odnotowywano „odrodzenie Lejzerkowej tradycji chanukowej”. Wiele spośród krakowskich synagog zorganizowało w tym roku koncerty dzieł Goldberga $^{85}$. Doszło nawet do spektakularnego konfliktu między krakowską gminą żydowską i zarządem synagogi Ahawas Raim a córką kompozytora, Sarą Salomeą, która dotąd zazdrośnie strzegła dzieł ojca i teraz wytoczyła proces wyżej wymienionym, oskarżając ich o bezprawne czerpanie korzyści majątkowych z wykonania Lejzerkowych „koncertów chanukowych”. Prawdopodobnie oskarżenie wkrótce wycofano. Obrońcą gminy żydowskiej został wówczas doktor praw i adwokat, a przy tym przewodniczący Żydowskiego Towarzystwa Muzycznego w Krakowie, Henryk Apte ${ }^{86}$.

Fenomen popularności Goldberga, który raczej nie porywał swoją sztuką wykonawczą, nie posiadał wykształcenia muzycznego ani choćby podstawowego warsztatu kompozytorskiego, jakim mógłby wzbudzić respekt „publiczności”, a o którym jego wierny uczeń Sperber dyplomatycznie pisał, że: „kłopotał się w swojej muzycznej twórczości z opracowaniem melodyki śpiewu nusach oraz harmoniki muzycznych zdań chóru”, odsłania może najważniejszy czynnik decydujący o kierunku rozwoju

${ }^{85}$ Dokumenty synagogi Izraelitów Postępowych, AŻIH, zesp. 107: Gmina Wyznaniowa Żydowska w Krakowie 1822-1939, sygn. 689 [bez paginacji]; Meloman, Di banejung..., s. 7; tenże, Ingichn a cwejter grandiezer koncert fun liturgiszer muzik, „Di Post” (1938), nr 2, s. 7; Kronika. Pesach w Krakowie..., „Nowy Dziennik” (1938), nr 107, s. 11; Henryk Apte, Koncert synagogalny, „Nowy Dziennik” (1939), nr 126, s. 10.

${ }^{86}$ Córka znanego kompozytora krakowskiego skarży o tantiemy autorskie, „Nowy Dziennik” (1938), nr 228a, s. 9; Brauner, Kach hitpalelu Jehudej Krakow..., s. 195-201. 
muzyki liturgicznej w przedwojennej Galicji - gust modlących się. A tym najwyraźniej odpowiadał ,poruszający, specyficznie żydowski urok” Goldbergowskich kompozycji, „,który pochodził z piosenek ludowych i chasydzkich nigunów". Jak dalej trafnie opisuje fenomen Goldberga Sperber:

Jest to doprawdy godne podziwu - i tu tkwi także geniusz Lejzerka - jak on bez żadnego wykształcenia teoretycznomuzycznego mistrzowsko opanował skomplikowaną dziedzinę żydowskiej kompozycji i harmonii. Tu, gdzie wykształcony w duchu europejskim kompozytor pomaga sobie wiedzą teoretyczną, jemu, chazanowi kształconemu w małym wołyńskim mieście, pomaga tylko jego genialna intuicja, jego potężny muzyczny zmysł ${ }^{87}$.

\section{Wnioski i perspektywy badawcze}

Przedstawiona w niniejszym artykule wstępna charakterystyka reformy żydowskiej muzyki liturgicznej w przedwojennej Galicji wskazuje jeszcze obszary niewiedzy, których wypełnienie jest konieczne dla pełnego omówienia tego zagadnienia. Wiele faktów historycznych związanych z rozwojem ruchu postępowego w Galicji pozostaje nadal nieznanych. Poza monografią Majera Bałabana poświęconą historii społeczności postępowej Lwowa ${ }^{88}$, pracą Leona Streita na temat Templu w Stanisławowie ${ }^{89}$ oraz publikacją Alicji Maślak-Maciejewskiej dotyczącą społeczności postępowej Krakowa ${ }^{90}$ nie istnieją analogiczne prace, które prezentowałyby dzieje ruchu postępowego w innych galicyjskich miastach. Ich brak uniemożliwia zestawienie i porównanie dat wprowadzenia chórów i organów do galicyjskich Templów, poznanie ich muzycznych praktyk. Badania nad reformą muzyki synagogalnej nie zostały też ukończone w odniesieniu do wschodnich i zachodnich sąsiadów Galicji. Ich wyniki umożliwiłyby, z jednej strony, wskazanie konkretnych źródeł inspiracji reformy płynących z Zachodu, a w konsekwencji odróżnienie ich od inicjatyw lokalnych, z drugiej zaś pozwoliłyby stworzyć historyczny model rozwoju muzyki synagogalnej we wschodniej Europie i szczegółowo opisać te elementy twórczości indywidualnych kantorów, które przejęli oni od swoich nauczycieli, oraz te, które im zawdzięczały kolejne pokolenia wykonawców i kompozytorów.

\footnotetext{
87 Sperber, Eliezer Goldberg..., s. 3.

88 Bałaban, Historia lwowskiej synagogi...

89 Streit, Dzieje synagogi postępowej...

90 Maślak-Maciejewska, Modlili się w Templu...
} 
Dotychczasowe wnioski płynące z przeprowadzonych analiz materiałów archiwalnych, prasowych, wspomnień i rękopisów nutowych zachęcają do zgłębienia tematu. Przełamują bowiem stereotypowe wyobrażenia o galicyjskiej ortodoksji i pogłębiają jej charakterystykę. Potwierdzają, że to gustom muzycznym i determinacji tej społeczności zawdzięczamy przetrwanie i dalszy rozwój wschodnioeuropejskiego chazanut, języka i stylu muzycznego, który choć tak silnie i jednoznacznie związany z jedną grupą etniczną i religijną, w sposób uniwersalny i zrozumiały przemawia do słuchaczy innych wyznań i narodowości. Ostatecznie trudno o muzykę wypracowaną w sposób bardziej demokratyczny: tworzoną przez muzyka wybieranego przez całą społeczność danej synagogi, dodatkowo narzucającą mu konkretny repertuar i sposób jego wykonawstwa, kontrolującą spełnianie przez niego oczekiwań społeczności za pomocą honorarium i ustalania wysokości przyznanego wynagrodzenia zależnego również od liczby miejsc wykupionych w synagodze, do której najskuteczniej przyciągała atrakcyjna oprawa muzyczna.

W tym świetle jeszcze wyraźniejsze stają się takie cechy galicyjskiej społeczności żydowskiej, jak ogromna wrażliwość muzyczna, przyznanie muzyce ważnej roli w życiu społecznym i religijnym oraz wielkie przywiązanie do własnych tradycji muzycznych, od których nie odwiodła jej pokusa awansu społecznego, uznania ze strony elit (żydowskich i nieżydowskich) czy nawet wizja utworzenia państwa żydowskiego w Palestynie. Z tej perspektywy Żydzi galicyjscy zdają się odrębną, choć otwartą na wiele wpływów zewnętrznych grupą, społecznością o silnie skrystalizowanej tożsamości - różnej od otaczających ją grup narodowych i etnicznych oraz odmiennej od pozostałych grup żydowskich zamieszkujących inne części Europy i świata.

\section{Bibliografia}

\section{1. Źródła archiwalne}

Archiwum Główne Akt Dawnych, Księgi metrykalne wyznania mojżeszowego, zesp. 300.

Archiwum Narodowe w Krakowie, Archiwum Związku Żydowskich Stowarzyszeń Humanitarnych B'nei B'rith w Rzeczypospolitej Polskiej w Krakowie, zesp. 557. Archiwum Uniwersytetu Jagiellońskiego: Jakubczyk-Ślęczka Sylwia, Życie muzyczne spoteczności żydowskiej na terenach dawnej Galicji w okresie międzywojennym, Kraków 2018, maszynopis pracy doktorskiej przygotowanej na Wydziale Historycznym Uniwersytetu Jagiellońskiego. 
Archiwum Żydowskiego Instytutu Historycznego, Gmina Wyznaniowa Żydowska w Krakowie 1822-1939, zesp. 107.

YIVO Archives, Sholem Perlmutter's Collection, RG 289.

\section{2. Źródła opublikowane}

Brzoza Czesław, Żydowska mozaika polityczna w Polsce 1917-1927 (wybór dokumentów), Kraków 2003.

„Di Chazonim Welt” 1933-1935.

„Chwila” 1919-1939.

„Gazeta Przemyska” 1887-1894.

„Nowy Dziennik” 1918-1939.

„Oesterreichisch-ungarische Cantoren-Zeitung” 1881-1903.

„Di Post” 1937-1939.

„Prager Tagblatt” 1876-1939.

Psalmy, tłum. Izaak Cylkow, Warszawa 1883.

„Tygodnik Żydowski” 1928-1939.

„Die Wahrheit” 1885-1938.

\section{Opracowania}

Bałaban Majer, Historia lwowskiej synagogi postępowej, Lwów 1937.

Błaszczyk Leon Tadeusz, Żydzi w kulturze muzycznej ziem polskich w XIX i XX wieku. Stownik biograficzny, Warszawa 2014.

Brauner Arje, Kach hitpalelu Jehudej Krakow, [w:] Ha-Jechudim be-Krakow - Chajeha we-churbana szel kehila atika, red. Shimon Lazar, Hajfa 1981.

Davidson Charles, Immunim Benusah Hatefillah I: A Study Text and Workbook for the Jewish Prayer Modes, Elkins Park 1996.

Edelman Marsha Bryan, Discovering Jewish Music, Philadelphia 2003.

Fater Isachar, Muzyka żydowska w Polsce w okresie międzywojennym, Warszawa 1997. Friedmann Aron, Lebensbilder berühmter Kantoren 2. Zum 100. Geburtstage des Königlichen Musikdirektors Professor weiland Louis Lewandowski, Berlin 1921. Frühauf Tina, The Organ and Its Music in German-Jewish Culture, New York 2012. Frühauf Tina, Salomon Sulzer: Reformer, Cantor, Icon, Berlin 2012.

Fubini Enrico, Historia estetyki muzycznej, tłum. Zbigniew Skowron, Kraków 2002. Gąsowski Tomasz, Między gettem a światem. Dylematy ideowe Żydów galicyjskich na przełomie XIX i XX wieku, Kraków 1996.

Goldberg Halina, "On the Wings of Aesthetic Beauty Toward the Radiant Spheres of the Infinite”: Music and Jewish Reformers in Nineteenth-Century Warsaw, „The Musical Quarterly" 101 (2018), nr 4.

Jakubczyk-Ślęczka Sylwia, La musique juive à Cracovie de l'entre-deux-guerres selon les informations du journal «Nowy Dziennik», „Scripta Judaica Cracoviensia” 9 (2011).

Levin W. Neil, Zavel Zilberts, Milken Archive of Jewish Music, https://www.milkenarchive.org/artists/view/zavel-zilberts/ [dostęp: 28 stycznia 2019]. 
Manekin Rachel, The Prayer House of a Galician Maskil: Joseph Perl's Synagogue Regulations, „Association for Jewish Studies Review” 42 (2018), nr 2.

Maślak-Maciejewska Alicja, Działalność Towarzystwa Agudas Achim i jego zwiazki z synagogami postępowymi we Lwowie i Krakowie, „Kwartalnik Historii Żydów” (2014), nr 1.

Maślak-Maciejewska Alicja, Modlili się w Templu. Krakowscy Żydzi postępowi w XIX wieku. Studium społeczno-religijne, Kraków 2018.

Maślak-Maciejewska Alicja, Poza działalnościa Ozjasza Thona - synagoga Tempel i krakowskie Stowarzyszenie Izraelitów Postępowych w okresie międzywojennym, „Kwartalnik Historii Żydów” (2016), nr 1.

Maślak-Maciejewska Alicja, Wydarzenia patriotyczne organizowane w synagodze Tempel w Krakowie, [w:] Synagoga Tempel i środowisko krakowskich Żydów postępowych, red. Michał Galas, Kraków-Budapeszt 2012.

Matis Benjamin, An Annotated Translation of Pinchas Szerman's "Poilishe Khazones in Fargangenheitun Tzukunft" [The Polish Cantorate in the Past and the Future], 1924, „Scripta Judaica Cracoviensia” 14 (2016).

N'ginoth Baruch Schorr: Complete Service, According to the Traditional Ritual for New Year and Day of Atonement, red. Israel Schorr, New York 1906.

Orensztejn Cwi, Czortkow we-ha-musika ha-jehudit, [w:] Sefer jizkor le-hanecahat kedoszej kehilat Czortkow, red. Jeszajahu Austridan, Hajfa-Tel Awiw 1967.

Plohn Alfred, Muzyka we Lwowie a Żydzi, „Muzykalia XIII. Judaica 4” (maj 2012), http://demusica.edu.pl/muzykalia-xiii-judaica-4/ [dostęp: 23 października 2018].

Rothmüller Aron Marko, The Music of the Jews: An Historical Appreciation, Cranbury 1975.

Rubin Emanuel, Baron John H., Music in Jewish History and Culture, Sterling Heights 2006.

Streit Leon, Dzieje synagogi postępowej w Stanisławowie, Stanisławów 1939.

Zaludkowski Elias, Kultur-treger fun der jidiszer liturgie: historisz-biografiszer iberblik iber chazones, chazonim un diriżorn, Detroit 1930.

Zimmermann Akiva, B'ron Yachad: Essays, Research and Notes on Hazzanut and Jewish Music, Tel Aviv 1988.

Zylbercwajg Zalman, Leksikon fun jidiszn teater, New York 1959.

\author{
Sylwia Jakubczyk-Ślęczka \\ Uniwersytet Jagielloński \\ sylwia.jakubczyk@uj.edu.pl
}

